\title{
MILTON'S TWO-HANDED ENGINE AS A CONCEPTUAL METAPHOR
}

\author{
Robert Tindol \\ Guangdong University of Foreign Studies, Guangzhou, China
}

\begin{abstract}
One of the longstanding mysteries of English poetry is the identification of the "two-handed engine" from John Milton's 1638 poem “Lycidas," with which Saint Peter threatens to "strike once, and strike no more" the clergy who have been remiss in their duties. A new way of looking at the image is to read the entire passage with George Lakoff and Mark Turner's theory of conceptual metaphors in mind. The strength of this approach is to show that identification of the two-handed engine should be considered within the context of the entire poem. As many commentators have argued, Lycidas's posthumous fate as the "genius of the shore" does not rest solely in the actions of Saint Peter, but instead involves a reconciliation that amalgamates elements of both Christianity and the classical world as well as nature. The conceptual metaphor thus provides a single combinatory image.
\end{abstract}

Keywords: John Milton, “Lycidas”, George Lakoff, Mark Turner, conceptual metaphor

\section{Article history:}

Received: 13 December 2019;

Reviewed: 14 December 2019;

Revised: 16 December 2019;

Accepted: 20 December 2019;

Published: 30 December 2019

Copyright (C) 2019 Rober Tindol

c) (7) (5) This open access article is published and distributed under a CC BY-NC 4.0 International EY LC License which permits non-commercial use, distribution, and reproduction in any medium, provided the original author and source are credited. Permissions beyond the scope of this license may be available at roberttindol@hotmail.com. If you want to use the work commercially, you must first get the authors' permission.

Citation: Tindol, R. (2019). Milton's Two-Handed Engine as a Conceptual Metaphor. English Studies at NBU, 5(2), 247-267. https://doi.org/10.33919/esnbu.19.2.4

Robert Tindol, PhD, is Associate Professor of English in the Faculty of English Language and Culture at the Guangdong University of Foreign Studies in Guangzhou, China. He teaches graduate courses in critical theory as well as a variety of courses in English and American literature, writing, and cultural studies. His publications include "Rowing to Sublimity: The "Stolen Boat" Episode from The Prelude", a study of William Wordsworth that appeared earlier this year in the journal Concentric.

E-mail: roberttindol@hotmail.com

https://orcid.org/0000-0002-0335-8556 
John Milton's pastoral elegy "Lycidas" has for almost four centuries been a cause for both poetic befuddlement and clarity. The background of the poem is very straightforward, however: a Cambridge University acquaintance of Milton's named Edward King was sailing from England to Ireland on 10 August 1637, when his ship smashed into rocks and sank, drowning everyone on board. ${ }^{1}$ King's friends and colleagues decided to publish a book containing elegies composed in his honor. Milton wrote "Lycidas" for the volume, ${ }^{2}$ and the rest is literary history.

Although the facts are straightforward and the poem accomplishes its intended goal of properly commemorating King, attempts at interpretation have nonetheless been remarkably complex and labored. One particularly enigmatic image from the poem for which generations of scholars have proffered explanations is the famous "two-handed engine" reference. Disagreements have arisen because Milton doesn't make explicitly clear what he had in mind as a physical object, nor does he make it any easier for the reader to interpret precisely how the image fits into the larger framework of the poem. Yet, as the critic Mark Womack notes (1997), readers have not been particularly hampered in not being able to identify the two-handed engine (p. 131). What I would like to argue is that the metaphor itself is perhaps vague but not confusing because it is a conceptual metaphor of the kind described by the cognitive theorists George Lakoff and Mark Turner. ${ }^{3}$ In other words, I hope to show that the two-handed engine may be ambivalent if we attempt to settle on a single object, but unproblematic if we are comfortable with a conceptual notion that allows the reader to contextualize the specific image within the larger metaphorical meaning of the entire poem.

The relevant lines occur approximately midway through the 193-line poem, at the end of a passage in which the narrator (one of Lycidas's fellow shepherds) invokes a succession of figures to contemplate the significance of Lycidas's passing. The final

\footnotetext{
1 Additional details are available in Lipking (1996), “The Genius of the Shore.”

2 The book was published in 1638 as Justa Eduardo King Naufrago. Milton republished “Lycidas” in 1645 in the book Poems of Mr. John Milton.

${ }^{3}$ I will refer throughout this paper to Lakoff and Turner’s 1989 book More Than Cool Reason.
} 
speaker of this section is probably Saint Peter, ${ }^{4}$ and it is clear that the holder of the "two massy keys" is either the same individual or else is in close consort with the wielder of the two-handed engine:

Last came, and last did go,

The pilot of the Galilean lake.

Two massy keys he bore of metals twain,

(The golden opes, the iron shuts amain).

He shook his mitered locks, and stern bespake:

"How well could I have spared for thee young swain,

Anow of such as for their belly's sake,

Creep and intrude, and climb into the fold?

Of other care they little reck'ning make

Than how to scramble at the shearers' feast

And shove away the worthy bidden guest.

Blind mouths! that scarce themselves know how to hold

A sheep-hook, or have learned ought else the least

That to the faithfull herdman's art belongs!

What recks it them? What need they? They are sped,

And when they list, their lean and flashy songs

Grate on their scrannel pipes of wretched straw.

The hungry sheep look up, and are not fed,

But swoll'n with wind, and the rank mist they draw,

Rot inwardly, and foul contagion spread,

Besides what the grim wolf with privy paw

Daily devours apace, and nothing said!

But that two-handed engine at the door

Stands ready to smite once, and smite no more." 5

If the pilot of the Galilean lake is indeed Saint Peter, then we are to understand that he performs his eternal function of staffing the door of heaven by wielding two keys - one made of gold that allows admittance, and one of iron that prevents admittance. The pilot informs the narrator that he could have had a less emotionally wrenching task

4 Edwards (2011), “The Pilot and the Keys,"p. 605. While acknowledging that critical opinion "identifies the pilot with Saint Peter," Edwards concludes that the Christ identification makes better poetic sense because "to admit...a figure who...cannot be at rest in any conventional specimen of the bucolic mode - is to testify that no regeneration of English society will be possible until its literature too has been restored by one who bears in his hand the keys of death and hell" (p. 618).

5 Lycidas, The Annotated Milton (1999), pp. 122-132. All quotations from the poem will be taken from this text. 
if he had been called upon instead to eulogize one of the many clergymen who, unlike Lycidas, were unworthy. The pilot then heaps a fair amount of invective against those clergymen for their shortcomings, pointing out that that the clergymen (or bad shepherds) are failing their flocks by not feeding them properly or protecting them from outside harm. However, the bad clergymen will get their just due, which will come in the form of a smiting that will require only a single blow.

Is Saint Peter referring to himself as the holder of the two-handed engine? We initially find him beside the door, and what eternal door would a clergyman desire even a corrupt clergyman - other than the eternal reward of walking through the door to heaven? The answer seems fairly unambiguous: the two-handed engine is an implement of retribution and/or punishment directed against those who do not perform their willingly assumed tasks with fidelity. But if the answer is really this simple, then why does Saint Peter not simply state that he will strike down the unworthy? Why is an inanimate object the subject of a sentence with an action verb? In other words, why is the two-handed engine itself seemingly the actor? Before these questions can be addressed, it is first necessary to review past interpretations, which are far too numerous to include in a single journal article. Thus, I will be fairly selective.

To begin at the heart of Milton criticism, we may do no better than peruse the handy volume published by noted Milton scholar C.A. Patrides in 1961. The list of contributors included essays from luminaries such as Cleanth Brooks, M.H. Abrams, and Northrop Frye. Patrides himself added a preface and an annotated version of "Lycidas" in which he refers to the two-handed engine reference as a "famous riddle" (p. 6n), and directs readers to the appendix, in which he includes more than 40 bibliographical entries of articles and commentary speculating on the identity of the image (pp. 240-241). Patrides takes no side in the debate, instead referring to the matter as "[t]he most curious aspect of the commentaries on "Lycidas." (p. 240).

Nor do any of the contributors to Milton's Lycidas offer a specific interpretation, although Northrop Frye provides a carefully supported answer in which he states that the question of "why" the image is present in the poem yields a single response "that 
illustrates how carefully the poem has been constructed" (p. 206). By contrast, Frye offers, the question of identity yields "forty-odd answers, none of them completely satisfactory" (p. 206).

As for the many other explanations, a brief sampling will presumably suffice. Leon Howard, in a 1952 essay, states that most critics through the years have favored one of two Biblical identifications for the two-handed engine: "the 'axe' laid at the root of those trees which do not bring forth good fruit, in Matthew 3:10 and Luke 3:9, and the 'two-edged sword' issuing from the mouth of the Lord in Revelation 1:16" (pp. 174-175). That may be, but the opinion is by no means unanimous. David Sansome, for example, thinks that the winnowing fan is also a perfectly good candidate. ${ }^{6}$ But if so, then surely the threshing flail is just as likely a two-handed implement.7 Moreover, the reaper's scythe is surely another likely choice. ${ }^{8}$ But harvesting is by no means the only metaphor that critics have associated with the two-handed engine. In a 1930 article, Donald C. Dorian concludes (after speculating on the shortcomings of various other suggestions) that 'the 'engine' was liberty, which 'hath a sharp and double edge'; the 'two hands'were those of parliament" [which] "had then only to seize this weapon, liberty, and 'smite once, and smite no more' in order (as Milton thought), to remove not only the corrupt clergy, but whatever was 'grievance and unjust' to the people" (p. 215). Harry F. Robins (1954) offers his own summation of identifications by claiming that "commentators have split into two groups, the first taking 'engine' to signify 'a weapon of war or destruction,'... and the second group allowing the word a figurative sense based upon the idea of dual function alone" (p. 28).

However, I return to the Patrides book, and especially to the essays by David Daiches and Northrop Frye which both argue that the poem transcends any single

\footnotetext{
6 According to the Winnowing entry in Wikipedia, the winnowing fan is an implement that is used to separate the wheat grain (the edible part) from the chaff (the part generally discarded) by throwing the cracked grain into the air and allowing the lighter chaff to float away.

7 This information comes from the Flail entry in Wikipedia. Before the winnowing fan is used to throw the wheat into the air, the grain is first cracked mechanically. In the old days this was done by literally beating the grain while it lay on the ground, typically with a two-stick implement that resembles the nunchuks that one sees in martial-arts movies.

8 Detailed information can be found in the Scythe entry in Wikipedia. I do not include the sickle, which is a one-handed device that is automatically eliminated from consideration as a "two-handed engine."
} 
tradition. Daiches, in fact, provides an overview of the poem that is helpful in contextualizing the role of Saint Peter, who after all is the center of attention in the two-handed engine passage:

In Lycidas Milton circles round the problem, and with each circling he moves nearer the centre (he is spiraling rather than circling), and he reaches the centre only when he has found a solution, or at least an attitude in terms of which the problem can be faced with equanimity. (p. 104)

Rather than fix upon the sanctity of Edward King, Daiches explains, the poem instead addresses "the fate of the poet-priest in all his aspects, both as individual and as social figure" (p. 114). Thus, it is unnecessary to dwell on the identity of the two-handed engine, Daiches adds, because "all that is really necessary for an understanding of the poem is to note that retribution is certain through a device which suggests purposive activity on the part of society" (p. 115).

And, last but not least, I should also include Stanley Fish, who did not contribute an essay to the Patrides collection but is arguably foremost among contemporary Milton scholars. In a 1976 review article, Fish acknowledges the importance of the two-handed engine "interpretive crux," (interestingly, a word that Patrides does not use), but suggests that this and other similar difficulties to be found in Milton's works "are problems that apparently cannot be solved," and moreover, "that they are not meant to be solved, but to be experienced" (p. 465).

If such luminaries as Fish and the contributors to the 1961 Patrides collection argue that one should not labor too arduously on a specific identity of the two-handed engine, then does the scholarly world really need yet another paper on the topic? My answer is that I have no intention of proffering another specific identity of the object, but instead a suggestion that cognitive metaphor theory may reinforce the views of Frye, Daiches and others that the various traditions invoked by Milton in the poem should be 
taken as a whole. ${ }^{9}$ To make this case, it is best to begin with the work that began in earnest with cognitive linguist George Lakoff and philosopher Mark Johnson's 1980 book Metaphors We Live By. Their central proposition is that metaphors are by no means simply literary decorations, but are actually a standard feature of everyday life. As Lakoff and Johnson write, "our fundamental concepts are organized in terms of one or more spatialization metaphors" that are "rooted in physical and cultural experience" (p. 17). Some years later, Lakoff collaborated on another book - this time with Mark Turner -titled More Than Cool Reason (1989). This work furthered the argument that metaphor is common in everyday experience and that poetic metaphor in fact comprises particularly elegant instances of language usage that is marked by "[the poets'] talent for using these tools, and their skill in using them" (p. ix). Although Lakoff and Turner do not explicate "Lycidas," they nonetheless provide novel readings of various poems, including "Because I Could Not Stop for Death," by Emily Dickinson, and “To a Solitary Disciple," by William Carlos Williams. The latter reading is especially suited to my own thesis, not because of any purported thematic relationship between the two poems, but rather because Lakoff and Turner make a compelling case for Williams's having achieved a novel poetic vision due to the way he employs both specific visual metaphors and then contextualizes them to create a more general impression.

The Williams poem forges a link between the physical appearance of a church (the "source domain") with a nuanced take on religion (the "target domain") that proceeds directly from an extended musing on the source domain (p. 63). How is this even possible? The answer is that the imagery, or "iconicity" of the poem, is presented in such a way that our understanding of the nature of religion is expanded. Lakoff and Turner explain the relationship as follows:

Iconicity provides an extra layer of metaphorical structure to the poem. As we have seen, the religious meaning of the poem is understood metaphorically in terms of images. The iconic layer is the mapping from he

\footnotetext{
9 At least one critic, Blaine Greteman (2009), has employed Lakoff and Johnson's work in analyzing Milton's metaphors. Greteman's essay, however, focuses on the prose works and does not concern "Lycidas."
} 
structure of the language to the structure of the image presented and to the overall meaning of the poem. Our intuition about the degree of organic unity of a poem is based on our unconscious recognition of just such coherences between the formal and conceptual aspects of the poem. (p. 157)

What makes the poem a unique expression of religion, and why cannot the same concepts be expressed by means of another vehicle? The answer is that the source domain and target domain are expressed in such a way that only an imagistic rendering in a lyric poem would fully express the sentiment. As Lakoff and Turner explain,

Imagination is the formation of an image, something the mind can "see," and which therefore provides a form of knowledge. Imagination can be understood via this metaphor as the power to arrive at knowledge by constructing an image, say, an image that allows one to overcome blockage by reperceiving the situation unconventionally. (p. 158)

One reason that the Williams poem is efficacious as a model for a conceptual reading of "Lycidas" is because Lakoff and Turner identify the former poem as employing a sort of two-stage metaphorical process:

First, it discusses how to look at a scene. In doing so, it makes considerable use of metaphor. Second, the poem as a whole can be given a metaphorical interpretation, in which the disciple to whom the poem is addressed is told how to understand the nature of religion in terms of the scene presented to him. (p 141)

My argument is that their interpretation of "To a Solitary Disciple" coincidentally addresses a poem very similar in metaphoric structure to the Pilot of the Lake passage from "Lycidas." Just as the former poem contains both information on how to interpret its imagery as well as a metaphoric guide to a larger interpretation, I argue that "Lycidas" also instructs the reader in how to understand the metaphoric connections in smaller detail, and at the same time how to arrive at a larger aesthetic and/or political and religious context. 
Metaphors are not difficult to come by in the passage, for Milton begins by identifying the speaker as a "pilot of the Galilean lake." The reader must bring certain pre-existing information to bear in understanding the lines, first of all that there is a similarity in guiding a ship through the water and directing a life on the proper path. Lakoff and Turner would undoubtedly identify the source concept as "life as a journey," which they identify throughout the book as a standard concept in Western culture. ${ }^{10}$ The argument is not at all to say that identifying a spiritual guide as a "pilot" is original and in fact, such is far from the case. Rather, the idea is to identify Milton's employment of the pilot in this passage as a particularly original insight into the human experience, and I argue that doing so is quite easy if one regards the larger context of the passage. In other words, there is nothing particularly original about identifying life - or certain aspects of it - as best led by a guide of some sort, nor is there anything original about calling this guide a pilot. But the larger context will hint at a new and original vision.

Thus, we begin with several Lakoff/Turner metaphors that are immediately recognizable: that "life is a journey," that "purposes are destinations," and that "time is a changer." The second and third conceptual metaphors identify the spiritual quest as a voyage necessitating a time integration, and further, as a destination that is by no means certain. Thus, "time is a changer" is a conceptual metaphor that can take several directions in "Lycidas" that each employs other conceptual metaphors: that "time is a destroyer," "time is a healer," "time is an evaluator," "time is a pursuer." In fact, I think that there are actually far more conceptual metaphors at work in just this opening line "The pilot of the Galilean lake." But this list of Lakoff/Turner conceptual metaphors should more than demonstrate the complicated metaphorizing that is going on in the poem.

Regardless of whoever or whatever this pilot is, he is already established as an integral participant in our humanness insofar as we strive to engage in a meaningful existence, and are constrained in doing so not only by the human time scale but also by

10 This and the other conceptual metaphors such as "freedom is up," "time is a destroyer," and so on, all come from More Than Cool Reason. The authors provide a useful index of metaphors at the end of their book, with references to textual pages in which they discuss the metaphors. 
certain forces - certainly religious and perhaps political as well - that are much larger than our own individual situations. And lest we miss this point, the very next line reminds us that the pilot is the keeper of two keys. The lines contain so many metaphors that they are worthy of repeating so that we can more easily keep track:

Two massy keys he bore of metals twain,

(The golden opes, the iron shuts amain)

The word "massy" is not a metaphor because it refers to the quality of a physical object that makes it heavy, and thus is "semantically autonomous" (Lakoff and Turner, 1989, pp. 111-112). Everyday objects and quantities are semantically autonomous if they "are grounded in the habitual and routine bodily and social patterns we experience, and in what we learn of the experience of others" (Lakoff and Turner, 1989, p. 113). However, "keys" is clearly a metaphor in that it satisfies Lakoff and Turner's requirements in which "the logic of the source-domain structure is mapped onto the logic of the target-domain structure" (p. 103). In this case, the source-domain structure is the physical door that is lockable and the matching key which locks and unlocks it, while the target-domain structure is the life-pathway that can be determined by admission or debarment to the door. Gold, of course, is a "good" metal that has many positive associations, while iron is a common or "base" material. Again, my purpose here is not to argue in favor of any specific religious interpretation of specific metaphors, but to highlight the complexity of the metaphors that Milton employs in the space of a few simple words. And finally, I should also add that the door serves as metonymy in that it "involves only one conceptual domain" (that is, a door and an interior region), and because "one entity in a schema is taken as standing for one other entity in the same schema, or for the schema as a whole" (Lakoff and Turner, 1989, p. 103). Thus, metaphor and metonymy work together to inform the reader that the pilot holds the "key" to a proper life both metaphorically and physically.

In the third line of the passage, the pilot begins addressing the narrator, directly referring to him as the "young swain." One of the themes of "Lycidas" is love, and it is not difficult to see not only the love of friendship in the relationship, but also a hint of 
romantic love, as exemplified by the insistence of Milton in referring to the surviving shepherd as the "swain." The poem begins with the reflections of another shepherd referred to as the swain, and this multiplicity of the theme of love as romantic and Platonic is reflected in the narrator's anxiety that he will himself be cut short by death before he has had a chance to fulfil his mission (in other words, he worries about a loss of self-realization by dying before love is consummated, but also a loss in not being of service to others). The narrator's other concern is in reconciling the hope of resurrection with the limiting fate of an Orpheus-type dismemberment-the fate that Edward King's body presumably suffered after it became water-logged-for somehow the good shepherd must transcend his physical shortcomings if he is to survive in spirit. The narrator's anxiety within the context of the poem concerns his success in protecting his flock, but there is an implied anxiety about the physical remains of his drowned fellow. Further, he feels concern for the flock because it will be left to the wolves if he happens to suffer the same fate as Lycidas.

All of these concerns are in the swain's mind as the pilot addresses him in the following lines:

How well could I have spared for thee, young swain,

Anow of such as for their belly's sake

Creep and intrude, and climb into the fold?

Of other care they little reck'ning make

Than how to scramble at the shearers' feast

And shove away the worthy bidden guest.

The pilot here employs a type of reasoning known as the reductio ad absurdum. The swain would not have to worry about commemorating his departed friend if the friend had been like so many other shepherds who are simply unworthy of love. What is most remarkable about this strategy is that it replicated the bifurcated structure that we have already seen in the passage, with the choice of gold or iron keys, and of course, the choice of literally sinking or swimming if the Galilean lake is intended to remind us of Peter's abortive attempt to walk on water. To truly commemorate the drowned Lycidas, 
the swain must also understand the implications of losing a fellow shepherd who is not worthy of commemoration.

This bipartite structure is further manifest in the next lines, in which the pilot changes tacks from explaining what choices the bad shepherds make at the expense of their flocks to precisely what actions they fail to accomplish:

Blind mouths! that scarce themselves know how to hold

A sheep-hook, or have learned ought else the least

That to the faithfull herdman's art belongs!

What recks it them? What need they? They are sped,

A sheep-hook might presumably be considered a viable choice for the identity of the two-handed engine, but it simply cannot be so because the action of the sheep-hook is clearly taken here to be a benefit for those who may be inclined to "wander." Once again employing the Lakoff and Turner conceptual metaphor "life is a journey," the wandering in this case is unambiguously a pathway to avoid for those who wish to remain righteous, and certainly a practice to avoid on the part of the clergy who are entrusted with the proper handling of the "sheep-hook" in keeping their flock on course. Also given is the fact that the sheep-herder must himself be on the proper course, or else he will lead the entire flock astray, whether he employs his sheep-hook or not.

On the other hand, the pilot seems to imply that the bad shepherds will not necessarily be disastrous in leading the entire flock astray, for there is nothing in these lines to suggest abject failure of the entire shepherding project. Rather, the peril is for a few individuals to wander astray on their own, which indeed puts them in danger of the truly bad actors (the wolves), just as the most common natural disaster for a sheep-herd would be for a few strays to be picked off because it is convenient and easy for the wolves to do so.

Moreover, the action of the sheep-herders may be inadequate as far as proper implementation of the sheep-hooks is concerned, but also because there is something deficient in the music they make. Like most shepherds and swains, the bad shepherds to 
which the pilot refers are adept in music, and we see no reason to think that their music is not superficially pleasant:

And when they list, their lean and flashy songs

Grate on their scrannel pipes of wretched straw.

The hungry sheep look up and are not fed,

But swoll'n with wind, and the rank mist they draw,

Rot inwardly, and foul contagion spread,

Are the "flashy songs" thus competent at the surface level, but nonetheless lacking import because of the other failings of the shepherds, or are they the cause of the failure? Presumably the former, because a song must at least be superficially pleasant to be "flashy," even though it may otherwise be produced as a "grate" and arise from an instrument made of "wretched" material. At any rate, the sheep may seem to be superficially "fed" (presumably meaning both literally fed and also "fed" with the words of sound doctrine), but in fact may only appear plump because of gas distention.

What is the final outcome? According to the pilot, the deficient shepherds should not become too complacent or they may suffer retribution:

But that two-handed engine at the door

Stands ready to smite once, and smite no more

Employing one final time the "life is a journey" metaphor, we may assume that the "door" refers to the passageway that the pilot controls with his gold and iron keys. The bad shepherds have lived their lives deserving a dose of the iron, so to speak, but we are still not clear precisely how they will get their due. Does retribution come after they are dead and face eternal judgment? Are the bad shepherds as a class (in other words, the contemporary clergy of John Milton's day) in danger of some sort of purging here on earth before they die? One can make the latter case by perusing the preface that Milton added to the 1645 edition, which reads as follows:

In this monody the author bewails a learned friend, unfortunately drowned in his passage from Chester [in W. England] on the Irish seas, in 1637. And by occasion foretells the ruin of our corrupted clergy, then in their height. 
As Dartmouth University's on-line John Milton Reading Room explains in a gloss, the original publication of "Lycidas" in Juste Eduardo King Naufrago contained no preface at all, while the Trinity Manuscript (a handwritten copy of various Milton poems discovered in the Cambridge library in the early eighteenth century), includes as a preface the first sentence quoted above but not the second. At any rate, the entire preface can be interpreted to mean that "ruin" may indeed befall a bad clergyman before Saint Peter has had a chance to choose the key of eternal reward or punishment. ${ }^{11}$ However, if only one strike is sufficient to accomplish the final result, then why mention the possibility of another, even if it is discounted? After all, a secular judgment on the church of the type that befell the Anglican Church in the early 1640s would be the first of two judgments, the second being eternal judgment at the door of heaven. ${ }^{12}$

One answer may be found if we review the passage from the Book of Matthew in which the keys are introduced. According to the passage, Jesus Christ awards Peter the keys of heaven for having recognized his divinity:

And Jesus answered and said unto him, Blessed art thou, Simon Barjona: for flesh and blood hath not revealed it unto thee, but my Father which is in heaven. And I say also unto thee, That thou art Peter, and upon this rock I will build my church; and the gates of hell shall not prevail against it. And I will give unto thee the keys of the kingdom of heaven: and whatsoever thou shalt bind on earth shall be bound in heaven: and whatsoever thou shalt loose on earth shall be loosed in heaven. (Matthew 16:17-19)

The key passage thus begins with a bipartite structure, not necessarily empowering Peter to bind anyone in either place, but declaring that anyone bound

\footnotetext{
11 Critical opinion on the matter, as is the case with the two-handed engine, is rather complicated. In his 2009 essay, Neil Forsyth is unambiguous in asserting the political changes from 1637 to 1645 in England to have accounted for Milton's having "called further attention to St. Peter's speech" (p. 697). However, Stephen B. Dobranski (2008) raises the interesting possibility that the 1645 preface may not have even been written by Milton but by someone at the publishing house (p. 402).

12 Robins, in his 1954 essay "Milton's 'Two-Handed Engine," believes that both the 1645 preface and the relevant lines in the poem refer to an eternal judgment. In particular, he rejects Edward S. Le Comte's 1950 assertion that the "smiting" alludes to a political consequence. In particular, I think that Robins has a point in critiquing Le Comte's claim that the pilot's words refer to John 10:12-13, in which Jesus says that he is a good shepherd because he refuses to leave his flock to the care of hirelings who may ineptly let sheep fall victims to wolves. The logic breaks down because the pilot's warning seems very general and comprehensive insofar as it applies to all clergymen. It is not merely an injunction against hiring incompetent underlings.
} 
while Peter is on earth shall also be bound in heaven, and conversely, whomever he looses (freed?) on earth shall be loosed in heaven. Once again, we may employ conceptual metaphors to sort out precisely what is getting bound and loosened in a single act that seemingly may have two separate pathways. If the semantically autonomous concept, or source domain, of binding is literally tying up an individual to limit his or her freedom of movement, then the target domain is the judgment that eventually is imposed on an individual who has for some period of time exercised his or her free will. Loosening, by contrast, must have as its source domain the act of freeing an individual from physical restraint, and the target domain must be a judgment that guarantees a judgment that is essentially a "not guilty" verdict. This binding and loosening is not solely an act that occurs in heaven after death, according to this passage, nor simply here on earth, but rather as an amalgamation of the two. To be "bound on earth" is therefore to have already been judged somehow to be derelict in duty, which is the judgment that the pilot is apparently levying against the bad shepherds. To be "loosed on earth," by contrast, is to have been judged to be in compliance of duty, even though there seems to be no earthly reward for having been righteous - or at least no reward that precludes premature death before one has even had the chance to live a full life of service and compliance. But eternal reward or punishment is also an integral part of the equation.

My conclusion is that the two-handed engine is simply not the final word for Lycidas within the context of the poem. The pilot may indeed have the power to strike those who have earned disfavor, but the strike seems almost an afterthought if one considers that there is no parallel "smiting" that can possibly apply to Lycidas the good shepherd. A conceptual reading of the metaphors of the passage therefore necessitates our relegating the pilot to the other voices on the list who have already provided only partial answers. Earlier in the poem, for example, Phoebus has touched the trembling ears of the swain after the latter's lamentations that Lycidas has missed a chance at earthly fame and accomplishment, assuring him that fame is not of this earth. What Phoebus does not assure him is that Lycidas's death has had any ultimate meaning. Next, 
the swain in a roundabout way inquires of the sea god Neptune by way of Triton whether some mishap of nature was responsible for Lycidas's death. After inquiring around, Triton replies that a bad boat constructed in inauspicious times was responsible. Again, the response provides an answer that transcends human understanding, but is still deficient: Lycidas did not die as a part of the natural order of things, but rather as an accident that is still unexplained. After this, the swain inquires of Camus, perhaps to understand whether Lycidas's untimely death can be reconciled in the world of scholarship. Camus's answer? Not really.

The progression of the swain is thus to begin with the gods of classical antiquity, who have no good answer, and then to nature, which also comes up short, and then to the secular world of learning, which seems too distraught to even form a good answer, and finally to Christianity, which contents itself with deeming the good shepherds such as Lycidas to be eligible for an eternal reward, and with smiting the bad shepherds such as Lycidas's inferior colleagues with a final judgment. But I would argue that the swain still has no answer about the significance of Lycidas's death.

What is the swain's next step? To call for the flowering of the world, which at least in part will serve to decorate the tomb of Lycidas, given that his body is lost and that no specific burial site can even be adorned. But surely a comprehensive adornment will serve to reintegrate Lycidas as much as possible, given that no other agency, classical, Christian or the world of nature or learning, has provided much hope for recovery. Thus, Lycidas may indeed be reintegrated, although not in his former state:

So Lycidas sunk low, but mounted high,

Through the dear might of Him that walked the waves!

Where other groves, and other streams along

With nectar pure his oozy locks he laves

And hears the unexpressive nuptial song,

In the blest kingdoms meek, of joy and love.

Lycidas will thus achieve resurrection, although this particular triumph is severely hedged with the inclusion of the word "mounted." As a final invocation of the 
Lakoff and Turner conceptual metaphor, this word can be taken as a literal mounting of an object on a wall or pedestal. The target domain is just as passive, suggesting an individual being displayed with little or no freedom of movement, so the rising is a mixed blessing for Lycidas, as is the laving of his locks, which seems to be little more than a funerary preparation of his body for display. Also, he is to be reintegrated in some sense with the human destiny of procreation, because he will also be rewarded with the "unexpressive nuptial song." In addition, he will be entertained by "all the saints above," and in a final amalgamation of classical mythology with Christian, will become the "genius of the shore." But as for Lycidas the shepherd full of promise, the past is done and the future is a compromise. There's nothing really to do other than for the swain to get on with his life.

In sum, the conceptual metaphors employed in the poem are associated with location, and existence, while metaphors associated with time are secondary and derivative. For example, "control is up" from the Lakoff and Turner list is obviously employed by Milton in the closing lines of the poem, when it becomes apparent that the departed Lycidas rises much like the heavenly bodies, and does so because of the influence of Jesus Christ. "Mortal is down" is also employed in our being assured that a Lycidas merely languishing in some obscure spot in the ocean is an undesirable outcome that calls for intervention, both human and divine.

However, both of these metaphors are problematic because the notion of control and freedom is quite contradictory, both for Milton and, I would submit, for Christianity in general. The Matthew 16 passage suggests that "binding" and "loosening" are relative terms at best, and that "binding" can in fact be a "freedom" from control, of sorts, while "loosening" can clearly be associated with religious adherence.

Therefore, certain other metaphors are highly problematic, including "being controlled is being kept down," which is seemingly the fate that Lycidas will suffer if no one memorializes him nor attempts to "recover" his lost body, either physically or figuratively. "Freedom is up" is likewise problematic, in the association of the freedom 
of everlasting life with servitude to the Christian God. In fact, virtually all of the conceptual metaphors employed by Milton are slippery in one way or another, and this is precisely how I would like to keep my promise to show that the "two-handed engine" passage embodies both metaphors of "how to look at a scene" as well as a way in which the "poem as a whole can be given a metaphorical interpretation," as Lakoff and Turner claimed for the William Carlos Williams poem "To a Solitary Reaper" (p. 141). And in doing so, I will also hopefully keep my promise to demonstrate that the two-handed engine is simply another metaphor whose identification is not particularly crucial to understanding the message of "Lycidas."

If the two-handed engine is simply another metaphor, then the structure must be along the following lines: the source domain is a dangerous hand-wielded instrument that can be used to discipline or otherwise judge the miscreant. The target-domain, quite simply, is the behavior that is in need of discipline. The two-handed engine is therefore associated with an act of punishment in which rectitude provides either an "attitude adjustment," in modern American parlance, or else a final accounting that leaves the disciplined party forever sorry for his or her transgressions, but with no hope of attaining a second chance. Likely we should assume the latter, considering that the pilot informs the swain that the two-handed engine strikes only once and never a second time. Final retribution seems to be the end-result of the employment of the two-handed engine, and whatever the precise effect on the body, it is quite certain that there is no avoiding the blow and that there is no way to prevent it once the swing has begun.

Another way of looking at the two-handed engine is via the "Great Chain metaphor," which Lakoff and Turner employ to describe the order that humans tend to impose on physical entities. Human beings are highest on the Great Chain, naturally, and are followed in descending order by animals, plants, fashioned objects (or "complex objects," as Lakoff and Turner describe them), and lowest of all, "natural physical things" (p. 171). ${ }^{13}$ The two-handed engine is obviously a complex object, and as such

\footnotetext{
13 The entire list can be found in this paragraph, although Chapter 4 of More Than Cool Reason is devoted entirely to the Great Chain of Being.
} 
resembles most closely the ship that the swain has been informed was most literally responsible for Lycidas's death. Thus, the Great Chain metaphor further reinforces the view that the pilot's action (if he is indeed the wielder of the two-handed engine) has its consequences, but that neither death by drowning in a defective ship, nor judgment by smiting with a two-handed engine, is sufficient to determine why Lycidas died and whether he continues in some alternate sense.

Therefore, I offer that the analysis of "Lycidas" in light of conceptual metaphors also points to the limitation of this metaphor as a final end for the just and righteous. True, the bad shepherds may very well receive their eternal judgment with the blow (and again, we must assume so given that the device strikes only once), but there is a way to circumvent this fate handed by the pilot, and this is the key to the "larger metaphorical interpretation" in the Lakoff and Turner scheme. I argue that the pilot offers only two options for the departed Lycidas, who indeed avails himself of the more preferable one. But the swain has not been satisfied with this solution, and continues to ask what has been the true meaning of Lycidas's life and whether he is truly gone from the earth in all senses both spiritual and physical. The pilot simply has nothing final to offer the swain for Lycidas in the choice of gold or iron keys, just as Phoebus has provided no comprehensive solace by saying that fame is a heavenly affair, and certainly not Camus, who can simply remark that the loss of Lycidas is indeed a blow to the world of learning.

The overall integration, then, suggests that Lycidas can indeed be memorialized in such a way as to preserve his continued relevance, but that this memorialization is not simply a function of his beatification alone, or of his joining the natural world after he has been properly flowered and laved, or of his vicarious participation in the marriage ritual when he is properly commemorated by his mates back at the university. In fact, the proper memorialization of Lycidas requires all of the above, and even then his continuance as a viable force in the living world will be quite limited.

On the other hand, the Matthew 16 passage can also be interpreted so as to suggest that our affairs on earth are in an integrated continuum with our affairs in 
heaven. Saint Peter, after all, is seemingly given the power, first, to bind or loose on earth, and second, the promise that the things he binds or looses on earth will also be bound or loosed in heaven. Perhaps the final conclusion to be reached is that "Lycidas" has a tricky way of suggesting that we go beyond the standard religious interpretation that provides us with an eternal paradise after death, but no continuance on earth, and actually suggests that we may be limiting the promise if we conclude that being "loosed in heaven" has no continuing physical consequences. But these consequences require a struggle such as that of the swain, and should not be relegated to a mere strike of a two-handed engine of some sort.

\section{References}

Daiches, D. (1961). From A Study of Literature. In C.A. Patrides (Ed.), Milton's Lycidas: The Tradition and the Poem (pp. 101-119). New York: Holt, Rinehart and Winston.

Dobranski, S. (2008). Editing Milton: The Case against Modernisation. Review of English Studies, 59(240), new series, 392-408. https://doi.org/10.1093/res/hgm030

Dorian, D. (1930). Milton’s ‘Two-Handed Engine”. PMLA, 45 (1), 204-215. https://doi.org/10.2307/457736

Edwards, M. (2011). The Pilot and the Keys: Milton's Lycidas 167-171. Studies in Philology, 108(4), 605-618. https://doi.org/10.1353/sip.2011.0025

Fish, S. (1976). Interpreting the "Variorum". Critical Inquiry, 2(3), 465-485. https://doi.org/10.1086/447852

Flail. (n.d). Retrieved July 31, 2017 from Wikipedia: en.wikipedia.org/wiki/Flail

Forsythe, N. (2009). "Lycidas": A Wolf in Saint's Clothing. Critical Inquiry 35(3), 684-702. https://doi.org/10.1086/600095

Frye, N. (1961). Literature as Context: Milton's Lycidas. In C.A. Patrides (Ed.), Milton's Lycidas: The Tradition and the Poem (pp. 200-211). New York: Holt, Rinehart and Winston.

Greteman, B. (2009). "Exactest Proportion": The Iconoclastic and Constitutive Powers of Metaphor in Milton's Prose Tracts. ELH, 76(2), 399-417. Retrieved from www.jstor.org/stable/27742941

Howard, L. (1952). "That Two-Handed Engine” Once More. Huntington Library Quarterly, 15(2), 173-184. https://doi.org/10.2307/3816301 
Lakoff, G. \& Johnson, M. (1980). Metaphors We Live By. Chicago: University of Chicago Press.

Lakoff, G., and Turner, M. (1989). More Than Cool Reason: A Field Guide to Poetic Metaphor. Chicago: University of Chicago Press. https://doi.org/10.7208/chicago/9780226470986.001.0001

Le Comte, E. (1950). “That Two-Handed Engine” and Savonarola. Studies in Philology, 47 (4), 589-606. Retrieved from www.jstor.org/stable/4172950

Lipking, L. (1996). The Genius of the Shore: Lycidas, Adamastor, and the Poetics of Nationalism. PMLA, 111(2), 205-221. https://doi.org/10.2307/463102

Matthew 16 (King James Version). (n.d.). Bible Gateway. Retrieved Oct. 25, 2019 from http://www.biblegateway.com/passage/?search=matthew+16\&version=KJV

Milton, J. (1638). Lycidas. Justa Eduardo King Naufrago. Cambridge: Thomas Buck and Roger Daniel.

Milton, J. (1645). Lycidas. Poems of Mr. John Milton. London: Humphrey Moseley. https://doi.org/10.1093/oseo/instance.00097520

Milton, J. (1961). Lycidas. In C.A. Patrides (Ed.), Milton's Lycidas: The Tradition and the Poem (pp. 1-9). New York: Holt, Rinehart and Winston.

Milton, J. (1999). Lycidas. In B. Raffel (Ed.) The Annotated Milton: Complete English Poems (pp. 122-132). New York: Bantam Dell.

Milton, J. (n.d.). In T. Luxom (Ed.) The John Milton Reading Room. Retrieved July 31, 2017 from www.dartmouth.edu/ milton/reading_room/lycidas/text.shtml

Patrides, C.A. (1961). Preface. In C.A. Patrides (Ed.), Milton's Lycidas: The Tradition and the Poem (pp. vi-viii). New York: Holt, Rinehart and Winston.

Robins, H. (1954). Milton's 'Two-Handed Engine at the Door' and St. Matthew's Gospel. The Review of English Studies, 5(17), 25-36. https://doi.org/10.1093/res/V.17.25

Sansone, D. (2006). How Milton Reads. Modern Philology, 103(3), 332-358. https://doi.org/10.1086/509002

Scythe. (n.d.). Retrieved July 31, 2017 from Wikipedia: https://en.wikipedia.org/wiki/Scythe

Winnowing. (n.d.). Retrieved July 31, 2017 from Wikipedia: https://en.wikipedia.org/wiki/Winnowing

Womack, M. (1997). On the Value of Lycidas. Studies in English Literature, 1500-1900, 37(1), 119-136. https://doi.org/10.2307/450776

Reviewers:

1. Tadd Graham Fernée, PhD, New Bulgarian University

2. Anonymous
Handling Editor:

Stan Bogdanov, PhD,

New Bulgarian University 